\title{
VORBERI C H T.
}

Dem Auftrage des verstorbenen Dichters gemäls, habe ich für den richtigen $\mathrm{Ab}$ druck seiner zurūckgelassenen Handscbrift eines Deutschen Anakreon gesorgt. Er hat bei der Übertragung derjenigęn Oḍen, die er auswählte, nicht genauer Übersetzer sein wollen, sondern vielmehr freier Nachahmer. Eben so wenig machte er sichs zum Zweck, bei jedem Stükke, das etwa seine Aufmerksamkeit an$z \circ g$, eine kritische Unterşuchung vorzunehmen, weder über einzele Stellen noch über die Echthẹt des Ganzen. Unter denjenigen dieser kleinen Gedichte, welche in der Urschrift die unverkennbarsten Spuren eines spätern Ursprungs tragen, giebt es manche so voll einzeler 
feiner Gedanken und anmuthiger Empfindungen, dafs sie, gekleidet in eine gleichförmig edle, Ramlerische, Sprache, gefallen mũssen, und dafs es Verlust wäre, sie ungenutzt zu lassen. So wird der unbefangene geschmackvolle Leser, und selbst der Kenner des Originals, bei dem das Gefühl nicht vom Wissen unterdrückt ist, an manchem Stück hier Wohlgefallen haben, das er im Griechischen Anakreon ausmerzen möchte. Auch hier wird Deutschland empfinden, wie viel es seinem Ramler schuldig ist, für den reineren Geschmack am Alterthum.

Berlin, 31 Merz r8o1.

Georg Ludewig Spalding 